\title{
Protein Synthesis at Synaptic Sites ON DENDRITES
}

\author{
Oswald Steward ${ }^{1}$ and Erin M. Schuman ${ }^{2}$ \\ ${ }^{I}$ Reeve-Irvine Research Center and Departments of Anatomy/Neurobiology and \\ Neurobiology and Behavior, College of Medicine, University of California at Irvine, \\ Irvine, California 92697; e-mail: osteward@uci.edu \\ ${ }^{2}$ Division of Biology, 216-76 Howard Hughes Medical Institute, California Institute of \\ Technology, Pasadena, California 91125; e-mail: schumane@its.caltech.edu
}

Key Words synaptic plasticity, long-term potentiation, gene expression, hippocampus

Abstract Studies over the past 20 years have revealed that gene expression in neurons is carried out by a distributed network of translational machinery. One component of this network is localized in dendrites, where polyribosomes and associated membranous elements are positioned beneath synapses and translate a particular population of dendritic mRNAs. The localization of translation machinery and mRNAs at synapses endows individual synapses with the capability to independently control synaptic strength through the local synthesis of proteins. The present review discusses recent studies linking synaptic plasticity to dendritic protein synthesis and mRNA trafficking and considers how these processes are regulated. We summarize recent information about how synaptic signaling is coupled to local translation and to the delivery of newly transcribed mRNAs to activated synaptic sites and how local translation may play a role in activity-dependent synaptic modification.

\section{INTRODUCTION}

Synapses can undergo long-lasting changes in strength that likely contribute to learning and memory. Many studies that have used protein synthesis inhibitors have shown that long-lasting forms of behavioral and synaptic plasticity require protein synthesis (Davis \& Squire 1984, Bailey et al 1996, Kang \& Schuman 1996, Mayford et al 1996, Nguyen \& Kandel 1996, Schuman 1999). According to this idea, behavioral experience or electrical activity at synapses induces the synthesis of particular proteins that are critical for establishing enduring modifications. Possible roles for newly synthesized proteins include replacing degraded proteins, increasing the levels of existing proteins, or expressing novel or alternatively spliced forms of proteins. 
Newly synthesized proteins must be made from messenger RNAs (mRNAs) that are present constitutively or from mRNAs that are synthesized as a consequence of transcriptional activation. If the required proteins are made using existing mRNAs, then there must be a mechanism for regulating translation via synaptic activity. As discussed below, there exist signal transduction pathways that are activated by synaptic events, resulting in the stimulation of translation. If new gene expression is required, there must be signaling from the synapse to the transcriptional machinery of the neuron.

Recently synthesized proteins also need to be made available, selectively, to those synapses undergoing changes in strength. The observation that individual neurons are endowed with so many synapses suggests the capability of independently processing and storing many bits of information. Electrophysiological experiments have confirmed this to some extent; anatomically isolated groups of synapses on the same cell can be modified independently. That is, given two sets of afferents that converge on the same postsynaptic cell, the enhancement of synaptic strength at one set of afferents does not spread to enhance synaptic strength at the other set of afferents (e.g. Andersen et al 1977). This property of synaptic plasticity is often referred to as "input specificity."

In the CA1 region of the hippocampus, input specificity holds only if the two sets of afferents are spatially remote. If they are close $(<\sim 50 \mu \mathrm{m})$, there may be some heterosynaptic enhancement (Bonhoeffer et al 1989, Engert \& Bonhoeffer 1996, Schuman \& Madison 1994). Hence, it may be more accurate to describe long-term potentiation (LTP) in the CA1 region as "site" rather than "input specific." In the dentate gyrus, the situation is somewhat different in that activation of one set of afferents to a particular dendritic segment produces LTD at inactive synapses that terminate nearby (a form of heterosynaptic depression; see Levy \& Steward 1979, 1983). Again, this heterosynaptic interaction does not occur when inputs are spatially separate (White et al 1988, White et al 1990).

Given these issues of specificity and protein synthesis dependence, there must exist cell-biological mechanisms that allow synapses to independently control their strength. If the source of new proteins is the soma, neurons could utilize known protein transport and targeting mechanisms coupled with a "tag" or "marker" generated by synaptic activity (Martin et al 1997, Frey \& Morris 1997). According to this idea, newly synthesized proteins are selectively deposited or stabilized at sites containing the tag. Another solution involves the local, rather than somatic, synthesis of proteins at synaptic sites. This idea circumvents the need for a protein trafficking/capture mechanism, but does potentially require a mechanism for targeting the mRNA to activated synapses.

The notion of dendritic protein synthesis had its roots in the discovery of synapse-associated polyribosome complexes (SPRCs)—polyribosomes and associated membranous cisterns that are selectively localized beneath postsynaptic sites on the dendrites of central nervous system (CNS) neurons (Steward 1983, Steward \& Fass 1983, Steward \& Levy 1982). Based on the assumption that form implies function, the highly selective localization of SPRCs beneath synapses 
suggested the following: (a) the translation machinery might synthesize key molecular constituents of the synapse, and $(b)$ translation might be regulated by activity at the individual postsynaptic sites. As discussed below, there is now substantial evidence to support these ideas. In addition, many of the mRNAs that are present in dendrites have been identified; there is now considerable evidence that these mRNAs enable a local synthesis of the encoded proteins (Steward et al 1996, Steward \& Singer 1997).

What has been missing until recently is a link between synaptic activation and either the transport of mRNAs into dendrites or the local translation of these mRNAs on site. In this review, we summarize some of the recent data that establish this link and also begin to address the mechanisms underlying mRNA trafficking and local translation. We begin with a brief review of the nature of the proteinsynthetic machinery that is present at synaptic sites and provide an update regarding mRNAs that are localized in dendrites (and thus potentially are present at SPRCs). We summarize recent evidence that local translation of mRNA at the synapse may be regulated by synaptic activity and then summarize new information regarding how afferent activity regulates the translation and trafficking of dendritic mRNAs. We review the data suggesting that dendritic protein synthesis plays a key role in long-term synaptic modifications. Finally, we consider how these pieces might fit together to suggest a mechanism by which protein synthesis at the synapse mediates long-term synaptic modifications induced by activity.

\section{THE MACHINERY FOR PROTEIN SYNTHESIS AT SYNAPTIC SITES}

\section{Localization}

Synapse-associated polyribosome complexes are precisely localized in the postsynaptic cytoplasm. One very important feature of SPRCs is the selectivity of their localization. Quantitative electron-microscopic analyses have revealed that the vast majority of the polyribosomes that are present in dendrites are precisely positioned beneath postsynaptic sites and are absent from other parts of the dendrite (Steward \& Levy 1982). SPRCs are most often localized at the base of the spine, in the small moundlike structures from which the neck of the spine emerges. Thus, SPRCs are located within or near the portal between the spine neck and the shaft of the dendrite- the route through which current must flow when spine synapses are activated. In this location, SPRCs are ideally situated to be influenced by electrical and/or chemical signals from the synapse as well as by events within the dendrite proper. An important implication of this selective localization is that there be some mechanism that causes ribosomes, mRNA, and other components of the translational machinery to dock selectively in the postsynaptic cytoplasm. The mechanisms underlying this highly selective localization remain to be established. 
Although most dendritic polyribosomes are localized beneath synapses, a few clusters of ribosomes are localized within the core of the dendritic shaft (Steward \& Levy 1982). It is not yet known whether these represent a different population than the synapse-associated polyribosomes. One possibility is that the polyribosomes in the dendritic core are associated with mRNAs that encode proteins that are not destined for synaptic sites but play some other role in dendritic function. This speculation is of particular interest given the functional diversity of the mRNAs that have been identified in dendrites (see below). Alternatively, the clusters of polyribosomes in the core of the dendrite may represent packets of mRNAs and ribosomes that are in transit from the cell body.

SPRCs are often associated with membranous organelles in a rough endoplasmic reticulum (RER)-like configuration. Serial section reconstructions of midproximodistal dendrites of dentate granule cells and hippocampal pyramidal cells revealed that $\sim 50 \%$ of the polyribosomes are found in association with tubular cisterns (Steward \& Reeves 1988). A common configuration is one in which the ribosomes seem to surround a blind end of a cistern. Thus, the SPRC/cisternal complex may be a form of RER that could allow the synthesis of integral membrane proteins or soluble proteins destined for release. Evidence in support of this hypothesis is considered in more detail below.

Interestingly, the cisterns with which SPRCs are associated are sometimes connected with a spine apparatus (Steward \& Reeves 1988). The significance of these connections is not known. One interesting hypothesis is that the spine apparatus may be involved in some aspect of posttranslational processing of proteins that are synthesized at the SPRCs (more on this below).

\section{Synapse-Associated Polyribosome Complexes at Different Types of Synapses}

SPRCs are present at spine synapses on different neuron types. Quantitative analyses of polyribosomes have been carried out on dentate granule cells, hippocampal pyramidal cells, cortical neurons, and cerebellar Purkinje cells. These analyses reveal that SPRCs are present in a roughly similar configuration in all of the spinebearing neurons that have been evaluated.

Estimates of the incidence of polyribosomes at spine synapses vary depending on the quantitative methods used. In evaluations of single sections, $\sim 11 \%-15 \%$ of the identified spines have underlying polyribosomes (Steward \& Levy 1982). However, this is clearly an underestimate because not all of the area under a spine is contained within a single section. Serial section reconstructions of dendrites in the dentate gyrus reveal that the actual incidence of polyribosomes in spines on mid-proximodistal dendrites is $\sim 25 \%$ (Steward \& Levy 1982). The estimates of incidence also depend on the counting criteria. Studies that have used serial section reconstruction techniques to evaluate the distribution of individual ribosomes (not polyribosomes) yield higher estimates of incidence (Spacek \& Hartmann 1983). For example, in pyramidal neurons in the cerebral cortex, $82 \%$ of the reconstructed 
spines had ribosomes in the head, $42 \%$ had ribosomes in the neck, and $62 \%$ had ribosomes at the base. In cerebellar Purkinje cells, $13 \%$ of the spines had ribosomes in the head, and $22 \%$ had ribosomes at the base. It is likely that an important reason for the higher incidence values in this study is that single ribosomes were counted rather than polyribosomes. In any case, it is clear that polyribosomes are a ubiquitous component of the postsynaptic cytoplasm in a variety of neuron types.

SPRCs are also present at nonspine synapses. There have been no detailed quantitative evaluations of polyribosome distribution in the dendrites of nonspiny neurons, but it is clear that the same basic relationships exist as in spiny dendrites. For example, polyribosomes are often present beneath shaft synapses in association with submembranous cisterns and are found beneath both asymmetric (presumed excitatory) and symmetric (presumed inhibitory) synapses. Polyribosomes are also localized beneath synapses on axon initial segments (Steward \& Ribak 1986). This localization is noteworthy for two reasons: first, it extends the generality of SPRCs to yet another type of postsynaptic location; second, most (perhaps all) synapses on axon initial segments use $\gamma$-aminobutyric acid as their neurotransmitter and are thus inhibitory. Axon initial segments also contain organelles that appear identical to spine apparatuses, known cisternal organelles. Based on the localization of subsynaptic cisternal organelles beneath both excitatory and inhibitory synapses on axon initial segments, it may be worthwhile to reconsider the possible functions of these enigmatic organelles. This is especially true because previous hypotheses have focused on functions that would be especially important at excitatory synapses and perhaps of minimal importance at inhibitory synapses (e.g. $\mathrm{Ca}^{2+}$ sequestration).

If protein synthetic machinery is localized at synapses in order to synthesize some of the components of the synaptic junction, one would expect SPRCs to be especially prominent at synapses during periods of synapse growth. This is the case. Polyribosomes are very abundant in the dendrites of developing neurons and again appear to be preferentially localized beneath postsynaptic sites, although the degree of selectivity has not been evaluated quantitatively (Steward \& Falk 1986).

\section{PROTEINS SYNTHESIZED AT SYNAPSES}

The discovery of polyribosomes beneath synapses focused attention on the question of what proteins were synthesized in the postsynaptic cytoplasm. The approaches that have been used to address this question include the following: (a) biochemical studies of proteins synthesized by subcellular fractions enriched in pinched-off dendrites, $(b)$ in situ hybridization analyses of the subcellular distribution of mRNAs in neurons, and (c) molecular biological analyses of the complement of mRNAs in isolated dendrites, most often from immature neurons grown in culture. 


\section{Proteins Synthesized in Subcellular Fractions}

Biochemical approaches take advantage of subcellular fractionation techniques that allow the isolation of synaptosomes with attached fragments of dendrites that retain their cytoplasmic constituents, including polyribosomes and associated mRNAs. We have called these "synaptodendrosomes" (Rao \& Steward 1991a). Others have used similar fractions prepared by filtration, which are termed "synaptoneurosomes" (Weiler \& Greenough 1991, 1993; Weiler et al 1997).

The major limitation in using synaptodendrosomes or synaptoneurosomes to study dendritic protein synthesis is that the fractions are contaminated with fragments of neuronal and glial cell bodies. For example, high levels of the mRNA encoding glial fibrillary acidic protein are present (Chicurel et al 1990, Rao \& Steward 1991b), and it is likely that there are also fragments of neuronal cell bodies containing mRNAs that are normally not present in dendrites. The problem of contamination can be partially circumvented by focusing on proteins that are synthesized in synaptosomes and then assembled into synaptic structures. For example, pulse-labeling techniques have been used to label the proteins synthesized within synaptosomes and then subcellular fractionation and detergent extraction techniques have been used to prepare synaptic plasma membranes and fractions enriched in synaptic junctional complexes (the postsynaptic membrane specialization and associated membrane). The proteins that were synthesized within the synaptodendrosomes and assembled into the synaptic plasma membrane and synaptic junctional complex were then characterized using polyacrylamide gel electrophoresis combined with fluorography (Leski \& Steward 1996, Rao \& Steward 1991a). This strategy has revealed characteristics of the labeled bands, but so far, the approach has not provided definitive identification of the labeled proteins. This combined strategy also has the limitation that it is useful only for proteins that are assembled into the synaptic membrane or synaptic junctional complex. Thus, proteins that are not assembled into the synapse are not detected.

Studies using synaptoneurosome fractions without the secondary purification step of subcellular fractionation have provided evidence for the dendritic synthesis of one novel protein that had not previously been identified-fragile X mental retardation protein (FMRP) (Weiler et al 1997). FMRP is encoded by the fmrl gene, which is affected in human fragile $\mathrm{X}$ syndrome. Treatment of synaptoneurosomes with agonists for metabotropic glutamate receptors caused a rapid increase in the amount of FMRP in the synaptoneurosome fractions, as determined by Western blot analysis. These data suggested that FMRP was being synthesized within the fractions and that the synthesis was enhanced by metabotropic glutamate receptor (mGluR) activation. This evidence has led to the idea that the neuronal dysfunction that is part of fragile $\mathrm{X}$ syndrome may result from a disruption of local synthesis of protein at synapses (Comery et al 1997, Weiler et al 1997).

There are some inconsistencies, however, in the story regarding fragile $\mathrm{X}$ mental retardation protein (FMRP). In the first place, in situ hybridization analyses indicate that FMRP mRNA is not evident in dendrites of neurons in vivo (Hinds et al 1993, 
Valentine et al 2000). One can conceive of reasons why an mRNA might not be detected in dendrites by in situ hybridization. For example, the mRNA could be present at levels that are below the threshold for detection by standard in situ hybridization techniques. This possibility must be reconciled with the biochemical data, however, which indicate an almost twofold increase in the amount of FMRP detectable by Western blots within 5 min after treatment with mGluR agonists (Weiler et al 1997). Presumably such a large change in protein concentration could be achieved only if the levels of the mRNA were substantial.

It has also been suggested that FMRP plays a role in the regulation of translation of mRNAs at synapses (Feng et al 1997). This hypothesis is based on two facts: (a) FMRP is an RNA-binding protein, and $(b)$ immunocytochemical studies reveal that the protein is localized at polyribosome clusters in neuronal dendrites. Localization at dendritic polyribosomes is also consistent with the hypothesis that FMRP is synthesized within dendrites. It is clear that the story regarding FMRP is an evolving one.

The only other identified protein that has been shown to be synthesized in synaptoneurosomes is the alpha subunit of calcium-/calmodulin-dependent protein kinase II (CAMKII) (Sheetz et al 2000). These studies involved metabolic labeling with ${ }^{35} S$-methionine followed by two-dimensional gel electrophoresis and fluorography or by immunoprecipitation of metabolically labeled protein using an antibody against CAMKII. Synthesis by fragments of neuronal-cell bodies or glia cannot be excluded in these experiments, but dendritic synthesis is supported by the observation that the labeling was regulated by treatment with neurotransmitters. Although it was already known that the CAMKII message is present in dendrites, this study documents that this mRNA is in actuality translated in synaptoneurosomes.

There have been continuing efforts to refine subcellular fractionation approaches so as to yield fractions of greater purity. In this regard, one recent study reported a fractionation approach that yields synaptosomes in which glial-fibrillary-acidicprotein mRNA is not detected by reverse transcription-polymerase chain reaction (Bagni et al 2000), suggesting a lack of contamination by glial fragments. Previously identified dendritic mRNAs such as those encoding CAMKII, Arc, and an inositol 1,4,5 triphosphate (InsP3) receptor InsP3R1were detected in the same fractions. These studies also demonstrated that the mRNA for CAMKII was associated with polysomes and that the fraction associated with polysomes was increased by neurotransmitter activation. Interestingly, the mRNA for FMRP was also detected in these fractions by reverse transcription-polymerase chain reaction. Thus, these fractions may represent a purer population of synaptodendrosomes than has been available previously, which could provide a means to identify novel dendritic mRNAs.

\section{mRNAs in Dendrites in Vivo}

Important clues about the identity of the proteins that may be synthesized at synapses have been obtained from in situ hybridization analyses that document the 
presence of particular mRNAs in dendrites. In most studies, dendritic localization has been inferred by the pattern of labeling in brain regions where neuronal cell bodies are concentrated in discrete layers and where there are distinct neuropil layers that contain dendrites and axons but few neuronal cell bodies (e.g. cortical regions including the hippocampus and the cerebellar cortex). Definitive evidence that the mRNA is in fact present in dendrites (and not in glial cells) can be obtained using nonisotopic in situ hybridization techniques. Dendritic localization can also be confirmed by studies of neurons in culture, although one must consider the possibility that neurons in culture may express an unusual complement of mRNAs or sort mRNAs in different ways than neurons in vivo.

One important caveat is that the presence of a particular mRNA in dendrites does not establish that the mRNA is translated at synapses. There are polyribosomes in dendrites that are not localized beneath synapses, and these polyribosomes could be associated with a different set of mRNAs than are translated in the postsynaptic cytoplasm (Steward \& Reeves 1988). Nevertheless, identification of mRNAs that are present in dendrites provides candidates for synapse-associated mRNAs that can be further evaluated in other ways.

Table 1 lists the mRNAs for which the evidence for dendritic localization in vivo is strong. All of the RNAs listed extend for several hundred micrometers from the cell body. Certain other mRNAs that are localized primarily in cell bodies may extend slightly into proximal dendrites. For example, it has been reported that the mRNAs for two protein kinase C substrates (F1/GAP43 and RC3) extend somewhat further into the proximal dendrites of forebrain neurons than other "cell body" mRNAs. (Laudry et al 1993). The differences in the distribution of mRNAs encoding F1/GAP43 and RC3 vs other cell body mRNAs are slight and indeed were not evident in studies using nonisotopic in situ hybridization techniques that produced heavy labeling over cell bodies (Paradies \& Steward 1997).

Taken together, the information on mRNAs in dendrites allows several generalizations:

1. A number of different mRNAs that encode unrelated proteins are present in dendrites. The proteins encoded by mRNAs that are present in dendrites include a variety of different classes of protein (Table 1), including cytoplasmic, cytoskeletal, integral-membrane, and membrane-associated proteins. The proteins also have very different functions. Thus, it is likely that the translation of these mRNAs subserves different aspects of cellular and synaptic function [for additional discussion of this point, see Steward (1997)].

2. All of the dendritic mRNAs that have been identified so far are expressed differentially by different types of neurons. This is especially evident when considering the mRNAs that are present in the dendrites of forebrain neurons vs cerebellar Purkinje cells. For example, the mRNAs for MAP2, CAMKII, dendrin, and Arc are found in forebrain neurons, but are not expressed at high levels by Purkinje cells. Purkinje cells, on the other 
hand, express a different complement of mRNAs including the InsP3 receptor and other $\mathrm{Ca}^{2+}$-interacting proteins, for example L7 and PEP19 (Bian et al 1996). These mRNAs are expressed by Purkinje cells and a few other neuron types. The fact that different mixtures of mRNAs are present in the dendrites of different cell types suggests that dendritic protein synthesis may have different purposes in different cell types.

3. Although a number of mRNAs are present in the dendrites of forebrain neurons, the patterns of expression and subcellular distributions of the mRNAs are different. The mRNAs encoding CAMKII, dendrin, and Arc (when induced) are localized throughout the dendrites. In contrast, the mRNA for microtubule-associated protein 2 (MAP2) is found at high levels in the proximal one third to one half of the total dendritic length, but it is not detectable in distal dendrites of most neurons. The mRNAs that are present in the dendrites of Purkinje cells also exhibit different localization patterns. For example, the mRNA for the InsP3 receptor is present throughout dendrites but is concentrated in the proximal one third of the total dendritic length. The mRNA for L7 appears to be more uniformly distributed throughout the dendrites (Bian et al 1996). Studies of the trafficking of the immediate early gene Arc also reveal that the complement of dendritic mRNAs can vary over time in an activity-dependent fashion (see below). These findings indicate that the capability exists for a different mixture of proteins to be synthesized locally at different times in different neuron types and different dendritic domains, providing a considerable complexity in the mechanisms underlying protein synthesis at synapses. Also, the variety of subcellular distributions implies that there must be multiple signals mediating mRNA localization within dendrites.

4. The presence of mRNAs encoding different classes of proteins implies the existence of different types of translational machinery in dendrites. MAP2, CAMKII, and Arc are nonmembrane proteins and thus would presumably be synthesized by free polysomes. In contrast, the InsP3 receptor is an integral membrane protein that presumably must be synthesized by membrane-bound ribosomes (RER). As noted above, electron-microscopic studies have revealed subsynaptic polyribosomes closely associated with membranous cisterns that may represent a form of RER (Steward \& Reeves 1988). However, the InsP3 receptor is also a glycoprotein; thus, there is the question of how the newly synthesized protein is glycosylated (see below).

5. The dendritic localization of some mRNAs may be developmentally regulated. For example, the mRNA for calmodulin can be detected by in situ hybridization in dendritic laminae of developing, but not mature animals (Berry \& Brown 1996). This is consistent with the idea that local dendritic protein synthesis is especially important during periods of synaptogenesis (Palacios-Pru et al 1981, 1988; Steward \& Falk 1986). Several other mRNAs have been shown to be present in the dendrites 


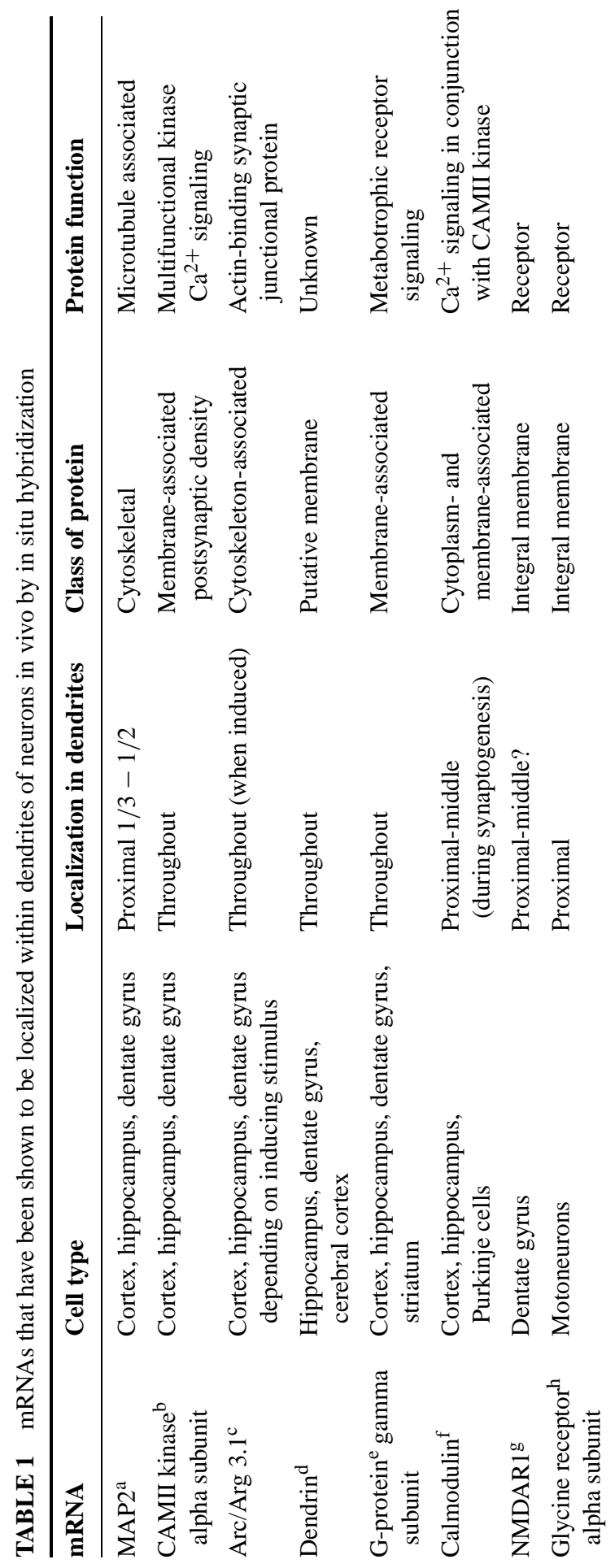




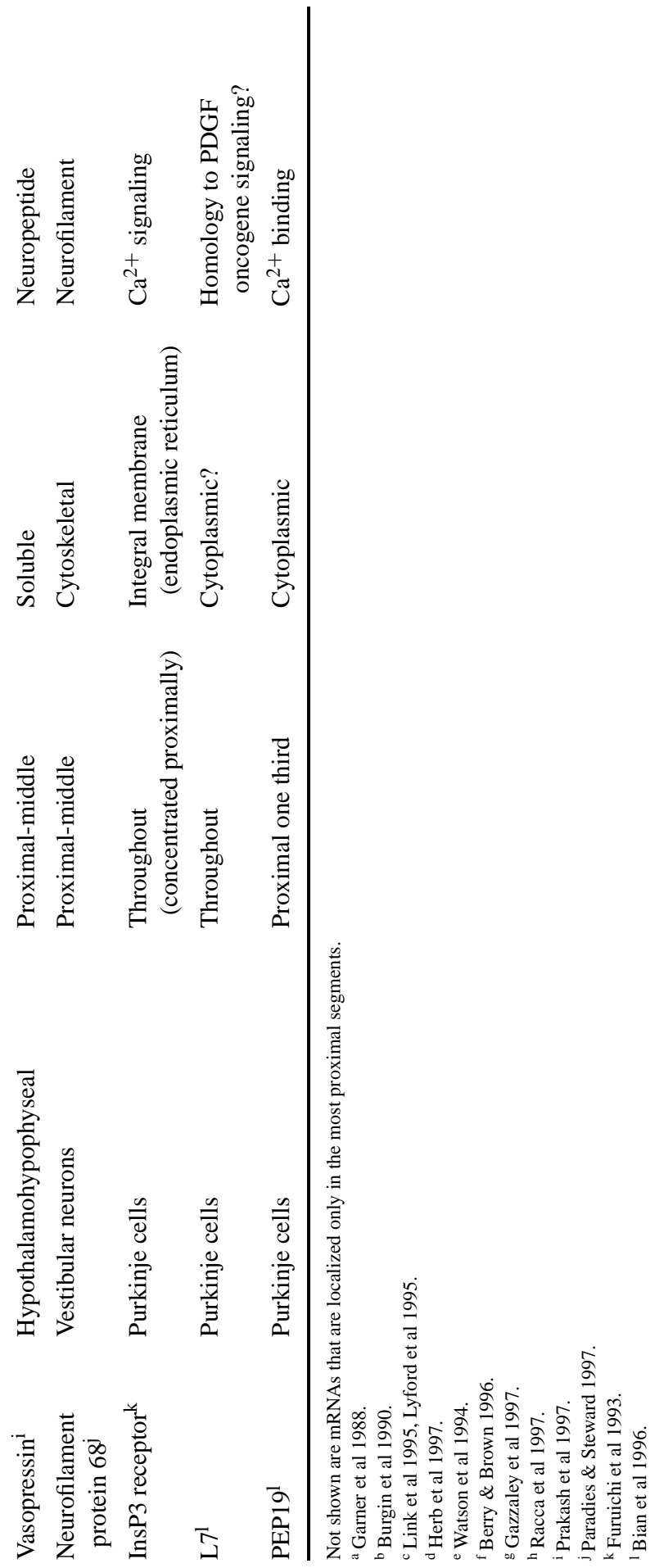


of young neurons developing in vitro. For example, the mRNAs for brain-derived neurotrophic factor (BDNF) and tyrosine kinase (trkB) receptors extend into the proximal $30 \%$ of the total dendritic length of hippocampal neurons in culture (Tongiorgi et al 1997). Potassium-induced depolarization (Tongiorgi et al 1997) or BDNF treatment (Righi et al 2000) increases the extent of dendritic labeling, so that the mRNAs extend to an average of $60 \%-70 \%$ of the total dendritic length. Despite the easily detectable dendritic labeling in neurons in vivo, the mRNAs for BDNF and trkB receptors appear to be largely restricted to the region of the cell body in young neurons in vivo (Dugich et al 1992). It remains to be seen whether a dendritic localization can be induced in neurons in vivo by manipulating neuronal activity.

Another mRNA that has been demonstrated in the dendrites of hippocampal neurons in vitro encodes the fatty acylated membrane-bound protein ligatin. Fluorescent in situ hybridization analyses indicate that the mRNA for ligatin extends for $>100 \mu \mathrm{m}$ into the dendrites of hippocampal neurons in culture; indeed, the dendritic labeling produced by ligatin probes is nearly as extensive as that produced by probes for CAMKII (Severt et al 2000). Nevertheless, previous studies of ligatin mRNA distribution in neurons in vivo reveal that the mRNA is largely restricted to the cell body region of hippocampal neurons in vivo (Perlin et al 1993). It is possible that the radioisotopic in situ hybridization techniques used in the earlier study in vivo were not sufficiently sensitive to detect mRNA in dendritic laminae.

\section{mRNAs in Dendrites of Neurons in Vitro}

One approach to identifying dendritic mRNAs has been to use patch pipettes to aspirate the cytoplasmic contents of individual dendrites of neurons grown in culture and then use RNA amplification techniques to clone the mRNAs (Miyashiro et al 1994). This study provided intriguing evidence that there may be a substantial number of mRNAs in dendrites, many of which remain to be characterized. However, there are certain inconsistencies between these and other findings. For example, the mRNAs for GluR1 receptors were detected, although the mRNAs for these receptors have not been detected by in situ hybridization in dendrites of neurons in vivo or in vitro. The reason for the disparity of results is not clear.

There are several possible explanations for the inconsistencies. One possibility is that Miyashiro et al analyzed cytoplasm from dendrites of very young neurons developing in culture. These might contain a different complement of mRNAs than the dendrites of mature neurons. Another possibility is that the amplification techniques detect mRNAs that are present in such low abundance that they are not easily detected using routine in situ hybridization techniques. It is also conceivable that some of the mRNAs in dendrites are in a form that somehow interferes with hybridization by complementary probes. 


\section{New Dendritic mRNAs}

It is almost certain that there are more dendritic mRNAs yet to be found. For example, biochemical studies of proteins synthesized within synaptodendrosomes suggest that several as yet unidentified constituents of synaptic junctions are locally synthesized within dendrites (Rao \& Steward 1991a, Steward et al 1991). The most prominent of these are not in a molecular-weight range that would be consistent with their being the translation products of known dendritic mRNAs. Systematic searches for new members of the family of dendritic mRNAs must deal with the problem of how to obtain sufficient quantities of mRNA from dendrites that are not contaminated by mRNA from neuronal cell bodies or supporting cells. So far, systematic searches have not yet identified new members of the family of dendritic mRNAs whose presence in dendrites in vivo was later confirmed by in situ hybridization analyses.

\section{Posttranslational Processing Within Dendrites}

The presence of mRNAs encoding integral membrane proteins raises the question of whether dendrites contain the machinery for posttranslational processing of recently synthesized proteins (specifically, components of the RER and Golgi apparatus [GA]). This question has been evaluated by assessing the distribution of protein markers and enzyme activities characteristic of the RER and GA (especially glycosyltransferase activities).

Initial studies evaluated the distribution of glycosyltransferase activities by pulse-labeling neurons with the sugar precursors that are the substrates of various glycosyltransferases that are present in the RER and GA. For example, mannose is added to nascent glycoproteins in the RER. Thus, when neurons are pulse-labeled with $\left[{ }^{3} \mathrm{H}\right]$ mannose under conditions in which transport of recently synthesized proteins is blocked, the sites of mannose incorporation can be revealed autoradiographically. The same strategy can be applied to higher-order glycosyltransferases that are characteristic of the GA, for example fucosyltransferase and galactosyltransferase. Studies of this type provided the initial evidence for the presence of both mannosyltransferase and higher-order (Golgi-like) glycosyltransferase activity in the dendrites of hippocampal neurons grown in culture (Torre \& Steward 1996).

Additional evidence regarding the localization of the RER and GA in dendrites has come from immunocytochemical studies of the subcellular distribution of proteins that are considered markers of the two endomembrane systems (Torre \& Steward 1996). Immunocytochemical studies of the distribution of ribophorin I (an RER marker) reveal staining that extends well into dendrites. In general, however, immunostaining for Golgi markers extended only into proximal dendrites. The immunocytochemical data were generally consistent with the autoradiographic evidence regarding the intracellular distribution of glycosyltransferase activity characteristic of the RER and GA. 
These data raise the question of what membranous organelles are actually responsible for the activities characteristic of the RER and GA. Recent electronmicroscopic immunocytochemical studies indicate that the membranous cisterns present near spine synapses stain for Sec6Ialpha protein complex, which is part of the machinery for translocation of proteins through the RER during their synthesis (Pierce et al 2000). The cisterns exhibiting labeling have the same appearance as the cisterns that represent the membranous component of SPRCs. Moreover, immunostaining for ribosomal protein S3 revealed labeling over the same membranous cisterns that were labeled for Sec6Ialpha.

The organelle responsible for higher-order glycosyltransferase (Golgi-like) activity remains to be identified. The studies of RER and GA distribution in dendrites imply that RER is present throughout dendrites whereas machinery for higher-order glycosylation may be present only in proximal dendrites, at least in hippocampal neurons in culture (Torre \& Steward 1996). Thus, if any integral membrane proteins are synthesized in distal dendrites of forebrain neurons, their glycosylation may be incomplete. In this regard, nonglycosylated membrane receptors can still function, although they may have different properties than fully glycosylated versions of the receptor (Giovannelli et al 1991). It will be of interest to determine whether the story is different in Purkinje cells, where the mRNA for at least one integral membrane protein is present throughout dendrites.

\section{REGULATION OF mRNA TRAFFICKING IN DENDRITES}

Evidence that synaptic activation triggers the transport of new mRNA transcripts to the synapse has come from studies of the immediate early gene Arc. Arc was discovered in screens for novel immediate early genes, defined as genes that are induced by activity in a protein synthesis-independent fashion (Link et al 1995, Lyford et al 1995). In both studies, the inducing stimulus was a single electroconvulsive seizure, and the protein synthesis independence was ensured by treating animals with cycloheximide to block protein synthesis (and hence the synthesis of secondary response genes). Arc was one of a number of novel immediate early genes that were identified using this paradigm.

Recent studies have revealed an interesting feature of the trafficking of Arc mRNA (Steward et al 1998). Patterned synaptic activation both induces Arc and causes the newly synthesized mRNA to localize selectively to activated dendritic domains. This was demonstrated in studies in which Arc expression was induced by stimulating the entorhinal cortical projections to the dentate gyrus in anesthetized rats. The projection from the entorhinal cortex to the dentate gyrus (the perforant path) terminates in a topographically organized fashion along the dendrites of dentate granule cells. Projections from the medial entorhinal cortex terminate in the middle molecular layer of the dentate gyrus, whereas projections from the lateral entorhinal cortex terminate in the outer molecular layer. Hence, by positioning a 
stimulating electrode in the medial entorhinal cortex, it is possible to selectively activate a band of synapses that terminate on mid-proximodistal dendrites.

When the medial perforant path was activated using a stimulation paradigm that is commonly used to induce LTP $(400-\mathrm{Hz}$ trains, 8 pulses per train, delivered at a rate of 1 pulse/10 s), Arc expression was strongly induced. The newly synthesized mRNA migrated into dendrites and accumulated selectively in the middle molecular layer in exactly the location of the band of synapses that had been activated. Similarly, activation of other afferent systems that terminate at different locations in the molecular layer caused the newly synthesized mRNA to localize selectively in other dendritic laminae. For example, simulation of the lateral entorhinal cortex produced a band of labeling for Arc mRNA in the outer molecular layer; stimulation of the commissural projection produced a band of labeling in the inner molecular layer (Steward et al 1998). Thus, these experiments revealed that synaptic activation generated a signal that caused Arc mRNA to localize near the active synapses. The nature of this docking signal remains to be defined.

Localization of Arc mRNA in activated dendritic laminae is associated with a local accumulation of Arc protein. Immunostaining of tissue sections from stimulated animals using an Arc-specific antibody revealed a band of newly synthesized protein in the same dendritic laminae in which Arc mRNA was concentrated (Steward et al 1998). The fact that synaptic activation leads to the selective targeting of both recently synthesized mRNA and protein suggests that the targeting of the mRNA underlies a local synthesis of the protein. Given that Arc protein is usually highly localized in postsynaptic junctions, it is likely that the newly synthesized Arc protein is targeted to the postsynaptic sites in the activated region. This remains to be established, however.

A number of pieces of the puzzle are still missing. First, it remains to be established whether Arc is directly involved in activity-induced synaptic modification. Additional clues to Arc's function will likely come from studies of the protein itself and its interactions with other functional molecules of the synaptic junctional region. But even if Arc does turn out to be a red herring, these studies have delineated RNA trafficking mechanisms that could be used for sorting other mRNAs that participate in activity-dependent modifications.

In addition to the induced $A r c$ mRNA there are other mRNAs present in dendrites constitutively. These include the mRNAs for molecules that have already been strongly implicated in activity-dependent synaptic modification (e.g. the alpha subunit of CAMII kinase). The mRNAs that are present constitutively provide an opportunity for local regulation of the synthesis of key signaling molecules via translational regulation (see below). Hence, protein synthesis at individual synapses may be regulated in a complex fashion, first through the regulation of the mRNAs available for translation (i.e. Arc) and then by regulation of the translation of the mix of mRNAs that are in place, including those present constitutively. How this is coordinated and how all of these molecules actually fit in to the molecular consolidation process remain to be established. 


\section{mRNA Binding Proteins}

It is very likely that mRNAs are transported into dendrites in RNA-protein complexes, which contain trans-acting factors responsible for RNA transportation as well as components of translational machinery (Knowles et al 1996). In the future, identification of the minimal cis-elements sufficient for dendritic RNA targeting should facilitate the characterization of the trans-acting factors that are involved in this process. Several proteins that are involved in RNA targeting and asymmetric distribution have been described in Drosophila embryos and Xenopus oocytes. One such molecule is staufen, a protein required for the asymmetric distribution of specific mRNAs in Drosophila oocytes and neuroblasts. Recently multiple mammalian staufen-related genes have been identified (Kiebler et al 1999, Marion et al 1999, Tang et al 1999, Wickham et al 1999). At least two of them are present in hippocampal neurons. Immunostaining experiments indicate somatodendritic distribution patterns of the staufen protein in hippocampal neurons, with higher signals in the proximal dendrites compared with distal dendrites in adult hippocampal slices. The staufen distribution pattern overlaps with that of dendritic RNA in cultured neurons (Tang et al 1999). In addition, RNA-containing staufen protein particles move along microtubules in the dendrites (Kohrmann et al 1999, Tang et al 1999). Expression of a truncated staufen, lacking the microtubule-binding domain, decreases the amount of RNA detected in dendrites (Tang et al 1999). In addition, overexpression of staufen can increase the amount of clustering of RNA in cultured hippocampal dendrites (Tang et al 1999). These observations are consistent with a role for staufen in dendritic RNA targeting. The specific mRNAs that staufen binds in vivo remain to be determined, as does the potential regulation of staufen trafficking during synaptic plasticity.

\section{REGULATION OF mRNA TRANSLATION AT SYNAPSES}

The selective localization of ribosomes at synapses provides a mechanism for locally regulating the production of proteins; this is an ideal mechanism to produce proteins that are necessary for synaptic modification. Local protein synthesis could involve mRNAs already in place and/or mRNAs that are induced by synaptic activity and delivered into dendrites. Until recently, there was no experimental link between synaptic activity and either the transport of mRNAs into dendrites or the local translation of these mRNAs at synapses. Recent studies, however, have shown that synaptic activity can trigger the transport of new mRNA transcripts to synaptic sites, as discussed above, and modulate the translation of mRNAs already in place, as discussed below.

Initial evidence for synaptic modulation of protein synthesis within dendrites came from studies of protein precursor incorporation by hippocampal slices in vitro (Feig \& Lipton 1993). When the Schaffer collaterals were activated in the presence of the cholinergic agonist carbachol, there was an increase in $\left[{ }^{3} \mathrm{H}\right]$ leucine incorporation in dendritic laminae as revealed by high-resolution autoradiography. 
Interestingly, neither Schaffer collateral stimulation nor carbachol alone produced a similar increase in labeling. While the combination of stimulation and carbachol caused a clear increase in protein synthesis, there was no detectable change in synaptic strength.

Given the abundance of the mRNAs for the alpha-subunit of CAMKII and MAP2 in the dendrites of hippocampal neurons (Burgin et al 1990), one obvious experiment is to evaluate whether the dendritic synthesis of CAMKII or MAP2 can be modulated by synaptic activity. Two studies have addressed this question by stimulating afferent projections to the hippocampus and dentate gyrus and evaluating CAMKII levels using immunocytochemistry. Ouyang et al (1997, 1999) approached the question by delivering high-frequency stimulation to the Schaffer collateral system in hippocampal slices in vitro. They observed increased immunostaining for both phosphorylated and nonphosphorylated CAMKII in the dendritic laminae. The increase in nonphosphorylated CAMKII occurred within 5 min of high-frequency stimulation and was blocked by anisomycin, strongly suggesting that the kinase was synthesized in the dendrites. A fast transport of CAMKII from the cell bodies seemed unlikely given the distance of the CAMKII increases from the cell bodies (e.g. $\sim 150-200 \mu \mathrm{m}$ ) as well as the fact that these experiments were conducted at room temperature. In a related study, Steward and colleagues demonstrated that high-frequency $(400-\mathrm{Hz})$ stimulation of the perforant path projections to the dentate gyrus in vivo also causes increases in immunostaining for CAMKII in the activated dendritic laminae (Steward \& Halpain 1999). There were also alterations in the pattern of immunostaining for MAP2, but the nature of the changes was different than was the case for CAMKII. Specifically, the increases in immunostaining for MAP2 occurred in the laminae on each side of the activated lamina. The changes in immunostaining for MAP2 were diminished but not eliminated by systemic or local application of protein synthesis inhibitors. Surprisingly, however, the increases in immunostaining for CAMKII were not affected by inhibiting protein synthesis. Thus, high-frequency synaptic activity can cause domain-specific alterations in the molecular composition of dendrites, but only a portion of the change may be attributable to local protein synthesis. In comparing these results to those of Ouyang et al $(1997,1999)$, it is possible that different stimulation frequencies (e.g. $100 \mathrm{vs} 400 \mathrm{~Hz}$ ) differentially invoke local synthesis vs trafficking of CAMKII. In addition, these studies were conducted in different areas of the hippocampus.

Although these combined results suggest synaptic regulation of dendritic protein synthesis, the possibility that newly synthesized proteins were actually produced in the neuronal cell body and rapidly transported into the dendrites cannot be ruled out. In this regard, parallel studies in subcellular fractions provide important complementary evidence.

\section{Studies in Subcellular Fractions}

In addition to the FMRP studies discussed above, recent studies of synaptoneurosomes prepared from frog tectum have revealed a novel mechanism for 
synaptic regulation of the translation of the alpha subunit of CAMKII. There is evidence that the formation of eye-specific projections in the tectum is regulated by activity and that the $N$-methyl-D-aspartate (NMDA) receptors play an important role in this process (Sheetz et al 1997). Based on these findings and the fact that CAMKII mRNA is present in dendrites, Sheetz et al (2000) evaluated how NMDA receptor activation of synaptoneurosomes from the tectum modulates CAMKII synthesis. Their results revealed a surprising and complex translation regulation mechanism. NMDA receptor activation did enhance CAMKII synthesis within the subcellular fractions (presumably within the synaptoneurosomes). At the same time, however, there was an increase in the phosphorylation of the initiation factor IF2, which would be expected to decrease the rate of polypeptide elongation (slowing the overall protein synthesis rate). This apparent paradox can be explained by the fact that studies of mRNA competition in translation assays reveal that decreases in elongation favor the translation of weakly initiated mRNAs. CAMKII is one of the mRNAs for which initiation is inefficient, and so general decreases in elongation consequent to IF2 phosphorylation could lead to increases in CAMKII synthesis. Sheetz et al (2000) also provided evidence in support of this idea by showing that low to moderate concentrations of cycloheximide (which partially inhibited overall protein synthesis) caused increases in the synthesis of CAMKII at the same time that overall levels of protein synthesis were diminished. These results thus provided evidence for regulation of CAMKII mRNA translation via NMDA receptor activation.

Other recent studies using synaptoneurosomes have revealed another novel mechanism for the control of the translation of CAMKII mRNA at synapses (Wu et al 1998). An unusual feature of CAMKII mRNA is that it contains a sequence in its $3^{\prime}$-untranslated region that is a consensus sequence for the binding of a cytoplasmic polyadenylation element (CPE). CPEs are known to play a key role in regulating the translation of maternal mRNAs in oocytes. These mRNAs, which are inherited from the mother, have a selective localization in the oocyte cytoplasm. The proteins encoded by these maternal mRNAs are often transcription factors that regulate the development of polarity in the embryo (i.e. defining dorsal vs ventral, anterior vs posterior, and particular body regions).

Maternal mRNAs are translationally repressed until fertilization. Upon fertilization, translation repression is relieved through the action of the CPE. Translationally repressed maternal mRNAs have very short poly-A tails. At fertilization, CPE is activated and triggers an elongation of the poly-A tail, resulting in translation induction. In an interesting experiment, Wu et al (1998) demonstrated that the translation of CAMKII kinase was regulated in a similar way in brain. In particular, NMDA receptor activation triggered polyadenylation of the mRNA for CAMII kinase, which in turn increased the synthesis of CAMKII protein. They further showed that this activation could be triggered by behavioral experience (light exposure for animals raised in the dark). This study thus revealed a second mechanism through which CAMKII protein synthesis could be regulated at the synapse. It remains to be seen how this 
mechanism interacts with the mechanism suggested in the experiments by Sheetz et al (2000).

Taken together, this evidence suggests a complex regulation of the translation of mRNAs at synapses. Activation of particular neurotransmitter receptors appears to play a role in regulating translation, and both metabotropic and NMDA-type receptors have been implicated in this process. It remains to be determined whether different mRNAs are controlled in different ways or whether different control mechanisms are present at different types of synapses.

\section{Coupling Synaptic Activity to Translation}

The signal transduction events that couple synaptic events to the protein translation machinery are not yet well understood. One signaling pathway that is stimulated by growth factors and results in the translation of several mRNAs includes the rapamycin-sensitive kinase mammalian target of rapamycin [mTOR, also known as FRAP kinase and RAFT-1; see Brown \& Schreiber (1996) for a review]. Several components of this translational signaling pathway, including mTOR, 4E-BP1, 4EBP-2, and eIF-4E, are present in the rat hippocampus, as shown by Western blot analysis and immunostaining studies (Tang et al 1998). In cultured hippocampal neurons, the distribution of these factors overlaps substantially with a synaptic protein, synapsin-I, suggesting synaptic localization. Disruption of mTOR activity by rapamycin results in deficits in late-phase LTP expression induced by high-frequency stimulation, while the early phase of LTP is unaffected (Tang et al 1998). Rapamycin also blocks the synaptic enhancement induced by BDNF in hippocampal slices (Tang et al 1998) as well as the long-term synaptic facilitation induced by repeated presentations of 5-hydroxytryptamine (5-HT) at Aplysia synapses in culture (Casadio et al 1999). These results imply an essential role for the rapamycin-sensitive signaling in three different forms of synaptic plasticity that require new protein synthesis. The localization of this translational signaling pathway at synaptic sites may provide a mechanism that controls local protein synthesis at potentiated synapses.

\section{ROLE OF LOCAL SYNTHESIS IN SYNAPTIC PLASTICITY}

\section{Long-Term Potentiation}

It is now well accepted that the late phase of LTP requires both transcription and translation. Indeed, the term late-phase LTP is operationally defined as the temporal phase of potentiation that can be blocked by inhibitors of protein synthesis. Initial evidence came from studies of hippocampal LTP in vitro, which reported that three different translation inhibitors, emetine, cycloheximide, and puromycin, reduced the proportion of slices exhibiting LTP (Stanton \& Sarvey 1984). A fourth inhibitor, anisomycin, reduced only the magnitude of LTP of the population spike. In subsequent studies of LTP in the dentate gyrus in vivo, it was found that 
pretreatment with anisomycin did not block LTP induction, but did result in the decay of LTP over time (Frey et al 1988, Otani \& Abraham 1989, Otani et al 1989). Subsequent studies of LTP in hippocampal slices yielded similar results (protein synthesis inhibitors block the late phase of LTP but not the early phase). (Nguyen $\&$ Kandel 1997, Osten et al 1996). These studies and others provide the basis for the widely held conclusion that the synthesis of new proteins is required for long lasting (e.g. $\geq \sim 1 \mathrm{~h}$ ) potentiation at both the Schaffer collateral-CA1 synapses in the hippocampus and perforant path synapses in the dentate gyrus.

A recent study (Raymond et al 2000) has suggested that the "priming" of LTP by mGluRs is also mediated by stimulation of local protein synthesis. Priming refers to the transformation of a small, decaying potentiation into a long-lasting enhancement by either an agonist or a synaptic stimulation protocol. Activation of mGluRs (by a selective agonist) 20 min before a tetanus promotes LTP induction and persistence (Cohen \& Abraham 1996, Cohen et al 1998). The application of a protein synthesis inhibitor during mGluR activation prevents the priming effect (Raymond et al 2000). Given the rapidity of the priming effect ( $<20 \mathrm{~min}$ ), these data are consistent with a mechanism involving mGluR stimulation of translation in the dendrites. This suggestion is further supported by the observation (discussed earlier) that mGluR agonists can stimulate protein synthesis in synaptoneurosomes (Weiler et al 1997).

Although the above studies support the conclusion that the late phase of LTP requires transcription and translation, they do not indicate whether the new proteins are synthesized in the cell body or in the dendrites or, for that matter, whether the required protein synthesis occurs pre- or postsynaptically.

\section{Dissecting Sites of the Protein Synthesis Required for LTP}

One of the earliest studies linking dendritic protein synthesis to synaptic plasticity examined the protein synthesis dependence of potentiation induced by the growth factors BDNF and neurotrophin-3 (Kang \& Schuman 1995, 1996). Application of either BDNF or neurotrophin-3 to CA1 synapses caused a large and long lasting (2- to 3-h) enhancement of synaptic transmission (Kang \& Schuman 1995). Surprisingly, pretreatment with a protein translation inhibitor blocked both the early and late phases of the enhancement (Kang \& Schuman 1996). This early (e.g. within 10-min) requirement for protein synthesis is not consistent with a somatic origin, given the distance between the recording site (distal dendrites) and the cell bodies. Microlesion experiments, in which the synaptic neuropil was isolated from the cell bodies, showed directly that the protein synthesis source was not the cell bodies. Dendrites isolated from their cell bodies still exhibited growth-factorinduced synaptic potentiation that was sensitive to translation inhibitors. More recent experiments have shown that BDNF can stimulate the translation of a dendritically localized green fluorescent protein mRNA in isolated dendrites (Smith et al 1999). 


\section{Long-Term Depression}

Proteins synthesized in dendrites may also contribute to long-term decreases in synaptic strength or long-term depression (LTD). There are two forms of LTD, one that requires the activation of NMDA receptors and the other that requires the activation of mGluRs. Capitalizing on the link between mGluR activity and stimulation of dendritic protein synthesis, Bear and colleagues examined whether mGluR-dependent LTD requires protein synthesis that is local (Huber et al 2000). The induction of LTD by an mGluR agonist was inhibited by bath application of anisomycin or the postsynaptic infusion of mRNA cap analog $\mathrm{m}^{7} \mathrm{GpppG}$ (Huber et al 2000). In addition, dendrites dissociated from their cell bodies still showed mGluR agonist-induced LTD, although the anisomycin sensitivity of this plasticity was not examined. Taken together with the results above, these data indicate that locally synthesized proteins can contribute to bidirectional changes in synaptic strength.

\section{Long-Term Facilitation in Aplysia Species}

There is abundant evidence that long-term synaptic modifications in invertebrates also require local protein synthesis at or near synapses. An entire review could be written on this topic, so here we summarize the evidence only briefly. In Aplysia the molecular bases of behavioral sensitization have been studied in a variety of reduced preparations, including the synapses formed between isolated sensory and motoneurons in culture (Montarolo et al 1986). In this system, repeated applications of 5-HT result in a protein synthesis-dependent long-term facilitation of synaptic transmission between the sensory and motoneurons (Clark \& Kandel 1993, Martin et al 1997). When a single sensory neuron with a bifurcating axon contacts two different motoneurons, five pulses of 5-HT to one synapse, but not the other, results in synapse-specific long-term facilitation at the 5-HT-treated synapse (Martin et al 1997). This long-term facilitation requires local protein synthesis: restricted application of a translation inhibitor to the 5-HT-treated synapse blocks the facilitation (Martin et al 1997). The long-term facilitation can be "captured" by the neighboring "naive" synapse if it is treated with single application of 5-HT within a few hours (Casadio et al 1999, Martin et al 1997). The long-term (e.g. 72-h) expression of synaptic capture also requires local protein synthesis. If a translation inhibitor is coapplied with the single 5-HT pulse to the "naive," this synapse will no longer exhibit long-term facilitation (Casadio et al 1999).

\section{SUMMARY}

The presence of polyribosomes, translation machinery, and mRNAs in dendrites endows individual synapses with the capability to independently control synaptic strength through the local synthesis of proteins. Studies in the past few years have provided strong evidence linking synaptic plasticity to dendritic protein synthesis and mRNA trafficking. Relatively little is know about how these processes are 
regulated including the coupling of synaptic signaling to translation machinery, the selective translation of specific mRNAs present at synapses, and the specific delivery of newly transcribed mRNAs to activated synaptic sites. Future studies will no doubt continue to strengthen the idea that local control of synaptic mRNAs and proteins is essential for maintaining the complexity of synaptic connections in the nervous system.

\section{ACKNOWLEDGMENTS}

This work was supported by NIH NS12333(OS), NIH NS37292, NIMHMH49176, and HHMI (EMS).

\section{Visit the Annual Reviews home page at www.AnnualReviews.org}

\section{LITERATURE CITED}

Andersen P, Sundberg SH, Sveen O, Wigstrom H. 1977. Specific long-lasting potentiation of synaptic transmission in hippocampal slices. Nature 266:736-37

Bagni C, Mannucci L, Dotti CG, Amaldi F. 2000. Chemical stimulation of synaptosomes modulates alpha- $\mathrm{Ca}^{2+} /$ calmodulindependent protein kinase II mRNA association to polysomes. J. Neurosci. 20(RC76): 1-6

Bailey CH, Bartsch D, Kandel ER. 1996. Toward a molecular definition of long-term memory storage. Proc. Natl. Acad. Sci. USA 93:13445-52

Berry FB, Brown IR. 1996. CaM I mRNA is localized to apical dendrites during postnatal development of neurons in the rat brain. $J$. Neurosci. Res. 43:565-75

Bian F, Chu T, Schilling K, Oberdick J. 1996. Differential mRNA transport and the regulation of protein synthesis: selective sensitivity of Purkinje cell dendritic mRNAs to translational inhibition. Mol. Cell. Neurosci. 7: 116-33

Bonhoeffer T, Staiger V, Aertsen A. 1989. Synaptic plasticity in rat hippocampal slice cultures: Local "Hebbian" conjunction of pre- and postsynaptic stimulation leads to distributed synaptic enhancement. Proc. Natl. Acad. Sci. USA 86:8113-17

Brown EJ, Schreiber SL. 1996. A signaling pathway to translational control. Cell 86: 517-20

Burgin KE, Waxham MN, Rickling S, Westgate SA, Mobley WC, Kelly PT. 1990. In situ hybridization histochemisty of $\mathrm{Ca} /$ calmodulin dependent protein kinase in developing rat brain. J. Neurosci. 10:1788-89

Casadio A, Martin KC, Giustetto M, Zhu H, Chen M, et al. 1999. A transient, neuron-wide form of CREB-mediated long-term facilitation can be stabilized at specific synapses by local protein synthesis. Cell 99:221-37

Chicurel ME, Terrian DM, Potter H. 1990. Subcellular localization of mRNA: isolation and characterization of mRNA from an enriched preparation of hippocampal dendritic spines. Soc. Neurosci. Abstr. 16:353

Clark GA, Kandel ER. 1993. Induction of long-term facilitation in Aplysia sensory neurons by local application of serotonin to remote synapses. Proc. Natl. Acad. Sci. USA 90:11411-15

Cohen AS, Abraham WC. 1996. Facilitation of long-term potentiation by prior activation of metabotropic glutamate receptors. J. Neurophysiol. 76:953-62

Cohen AS, Raymond CR, Abraham WC. 1998. Priming of long-term potentiation induced by activation of metabotropic glutamate receptors coupled to phospholipase C. Hippocampus $8: 160-70$ 
Comery TA, Harris JB, Willems PJ, Oostra BA, Irwin SA, et al. 1997. Abnormal dendritic spines in fragile $\mathrm{X}$ knockout mice: maturation and pruning deficits. Proc. Natl. Acad. Sci. USA 94:5401-4

Davis HP, Squire LR. 1984. Protein synthesis and memory: a review. Psychol. Bull. 96:518-59

Dugich MM, Tocco G, Willoughby DA, Najm I, Pasinetti G, et al. 1992. BDNF mRNA expression in the developing rat brain following kainic acid-induced seizure activity. Neuron 8:1127-38

Engert F, Bonhoeffer T. 1996. Pairing-induced LTP in hippocampal slice cultures is not strictly input-specific. Soc. Neurosci. Abstr. 22:516

Feig S, Lipton P. 1993. Pairing the cholinergic agonist carbachol with patterned scaffer collateral stimulation initiates protein synthesis in hippocampal CA1 pyramidal cell dendrites via a muscarinic, NMDA-dependent mechanism. J. Neurosci. 13:1010-21

Feng Y, Gutekunst C-A, Eberhart DE, Yi H, Warren ST, Hersch SM. 1997. Fragile $\mathrm{X}$ mental retardation protein: nucleocytoplasmic shuttling and association with somatodendritic ribosomes. J. Neurosci. 17: 1539-47

Frey U, Krug M, Reymann KG, Matthies H. 1988. Anisomycin, an inhibitor of protein synthesis, blocks late phases of LTP phenomena in the hippocampal CA1 region in vitro. Brain Res. 452:57-65

Frey U, Morris RGM. 1997. Synaptic tagging and long-term potentiation. Nature 385:53336

Furuichi T, Simon-Chazottes D, Fujino I, Yamada N, Hasegawa M, et al. 1993. Widespread expression of inositol 1,4,5triphosphate receptor type 1 gene (Insp3r1) in the mouse central nervous system. Recept. Channels 1:11-24

Garner CC, Tucker RP, Matus A. 1998. Selective localization of messenger RNA for cytoskeletal protein MAP2 in dendrites. Nature 336:674-77
Gazzaley AH, Benson DL, Huntley GW, Morrison JH. 1997. Differential subcellular regulation of NMDAR1 protein and mRNA in dendrites of dentate gyrus granule cells after perforant path transection. J. Neursci. 17:2006-17

Giovannelli A, Grassi F, Eusebi F, Miledi R. 1991. Tunicamycin increases desensitization of acetylcholine receptors in cultured mouse muscle cells. Proc. Natl. Acad. Sci. USA 88:1808-11

Herb A, Wisden W, Catania DMV, Marechal D, Dresse A, Seeberg PH. 1997. Prominent dendritic localization in forebrain neurons of a novel mRNA and its product, dendrin. Mol. Cell Neurosci. 8:367-74

Hinds HL, Ashley CT, Sutcliffe JS, Nelson DL, Warren ST, et al. 1993. Tissue specific expression of FMR-1 provides evidence for a functional role in fragile $\mathrm{X}$ syndrome. Nat. Genet. 3:36-43

Huber KM, Kayser MS, Bear MF. 2000. Role for rapid dendritic protein synthesis in hippocampal mGluR-dependent long-term depression. Science 288:1254-56

Kang H, Schuman EM. 1995. Long-lasting neurotrophin-induced enhancement of synaptic transmission in the adult hippocampus. Science 267:1658-62

Kang H, Schuman EM. 1996. A requirement for local protein synthesis in neurotrophininduced synaptic plasticity. Science 273: 1402-6

Kiebler MA, Hemraj I, Verkade P, Kohrmann M, Fortes P, et al. 1999. The mammalian Staufen protein localizes to the somatodendritic domain of cultured hippocampal neurons: implications for its involvement in mRNA transport. J. Neurosci. 19:288-97

Knowles RB, Sabry JH, Martone ME, Deerinck TJ, Ellisman MH, et al. 1996. Translocation of RNA granules in living neurons. J. Neurosci. 16:7812-20

Kohrmann M, Luo M, Kaether C, DesGroseiller L, Dotti CG, Kiebler MA. 1999. Microtubule-dependent recruitment of Staufen-green fluorecent protein into 
RNA-containing granules and subsequent dendritic transport in living hippocampal neurons. Mol. Biol. Cell 10:2945-53

Laudry CF, Watson JB, Handley VW, Campagnoni AT. 1993. Distribution of neuronal and glial mRNAs within neuronal cell bodies and processes. Soc. Neurosci. Abstr. 19:1745

Leski ML, Steward O. 1996. Synthesis of proteins within dendrites: ionic and neurotransmitter modulation of synthesis of particular polypeptides characterized by gel electrophoresis. Neurochem. Res. 21:681-90

Levy WB, Steward O. 1979. Synapses as associative memory elements in the hippocampal formation. Brain Res. 175:233-45

Levy WB, Steward O. 1983. Temporal contiguity requirements for long-term associative potentiation/depression in the hippocampus. Neuroscience 7:791-97

Link W, Konietzko G, Kauselmann G, Krug M, Schwanke B, et al. 1995. Somatodendritic expression of an immediate early gene is regulated by synaptic activity. Proc. Natl. Acad. Sci. USA 92:5734-38

Lyford G, Yamagata K, Kaufmann W, Barnes C, Sanders L, et al. 1995. Arc, a growth factor and activity-regulated gene, encodes a novel cytoskeleton-associated protein that is enriched in neuronal dendrites. Neuron 14:43345

Marion RM, Fortes P, Beloso A, Dotti C, Ortin J. 1999. A human sequence homology of staufen is an RNA-binding protein that is associated with polysomes and localizes to the endoplasmic reticulum. Mol. Cell. Biol. 19:2212-19

Martin KC, Casadio A, Zhu H, E Y, Rose JC, et al. 1997. Synapse-specific, long-term facilitation of Aplysia sensory to motor synapses: a function for local protein synthesis in memory storage. Cell 91:927-38

Mayford M, Bach ME, Huang Y-Y, Wang L, Hawkins RD, Kandel ER. 1996. Control of memory formation through regulated expression of a CaMKII transgene. Science 274:1678-83

Miyashiro K, Dichter M, Eberwine J. 1994.
On the nature and differential distribution of mRNAs in hippocampal neurites: implications for neuronal functioning. Proc. Natl. Acad. Sci. USA 91:10800-4

Montarolo PG, Goelet P, Castellucci V, Morgan J, Kandel ER, Schacher S. 1986. A critical period for macromolecular synthesis in longterm heterosynaptic facilitation in aplysia. Science 234:1249-54

Nguyen PV, Kandel ER. 1996. A macromoleular synthesis-dependent late phase of longterm potentiation requiring CAMP in the medial perforant pathway of rat hippocampal slices. J. Neurosci. 16:3189-98

Nguyen PV, Kandel ER. 1997. Brief theta burst stimulation induced a transcriptiondependent late phase of LTP requiring cAMP in area CA1 of the mouse hippocampus. Learn. Mem. 4:230-43

Osten P, Valsamis L, Harris A. 1996. Protein synthesis-dependent formation of protein kinase $\mathrm{M}$ zeta in long-term potentiation. $J$. Neurosci. 16:2444-51

Otani S, Abraham WC. 1989. Inhibition of protein synthesis in the dentate gyrus, but not the entorhinal cortex, blocks maintenance of long-term potentiation in rats. Neurosci. Lett. 106:175-80

Otani S, Marshall CJ, Tate WP, Goddard GV, Abraham WC. 1989. Maintenance of longterm potentiation in rat dentate gyrus requires protein synthesis but not messenger RNA synthesis immediate post-tetanization. $\mathrm{Neu}$ roscience 28:519-26

Ouyang Y, Kantor DB, Harris KM, Schuman EM, Kennedy MB. 1997. Visualization of the distribution of autophosphorylated calcium/calmodulin-dependent protein kinase II after tetanic stimulation in the CA1 area of the hippocampus. J. Neurosci. 17:5416-27

Ouyang Y, Rosenstein A, Kreiman G, Schuman EM, Kennedy MB. 1999. Tetanic stimulation leads to increased accumulation of $\mathrm{Ca}(2+) /$ calmodulin-dependent protein kinase II via dendritic protein synthesis in hippocampal neurons. J. Neurosci. 19:7823-33 
Palacios-Pru EL, Miranda-Contreras L, Mendoza RV, Zambrano E. 1988. Dendritic RNA and postsynaptic density formation in chick cerebellar synaptogenesis. Neuroscience 24:111-18

Palacios-Pru EL, Palacios L, Mendoza RV. 1981. Synaptogenetic mechanisms during chick cerebellar cortex development. J. Submicrosc. Cytol. 13:145-67

Paradies MA, Steward O. 1997. Multiple subcellular mRNA distribution patterns in neurons: a nonisotopic in situ hybridization analysis. J. Neurobiol. 33:473-93

Perlin JB, Gerwin CM, Panchision DM, Vick RS, Jakoi ER, DeLorenzo RJ. 1993. Kindling produces long-lasting and selective changes in gene expression in hippocampal neurons. Proc. Natl. Acad. Sci. USA 90:1741-45

Pierce JP, van Leyen K, McCarthy JB. 2000. Translocation machinery for synthesis of integral membrane and secretory proteins in dendritic spines. Nat. Neurosci. 3:311-13

Prakash N, Fehr S. Mohr E. Richter D. 1997. Dendritic localization of rat vasopressin mRNA: ultrastructural analysis and mapping of targeting elements. Eur. J. Neurosci. 9:523-32

Racca C, Gardiol A, Triller A. 1997. Dendritic and postsynaptic localizations of glycine receptor alpha subunit mRNAs. J. Neurosci. 17:1691-1700

Rao A, Steward O. 1991a. Evidence that protein constituents of postsynaptic membrane specializations are locally synthesized: analysis of proteins synthesized within synaptosomes. J. Neurosci. 11:2881-95

Rao A, Steward O. 1991b. Synaptosomal RNA: assessment of contamination by glia and comparison with total RNA. Soc. Neurosci. Abstr. 17:379

Raymond CR, Thompson VA, Tate WR, Abraham WC. 2000. Metabotropic glutamate receptors trigger homosynaptic protein synthesis to prolong long-term potentiation. $J$. Neurosci. 20:969-76

Righi M, Tongiorgi E, Cattaneo A. 2000. Brain-derived neurotrophic factor (BDNF) induces dendritic targeting of BDNF and tyrosine kinase B mRNAs in hippocampal neurons through a phosphatidylinositol3 kinase-dependent pathway. J. Neurosci. 20:3165-74

Schuman EM. 1999. mRNA trafficking and local protein synthesis at the synapse. Neuron 23:645-8

Schuman EM, Madison DV. 1994. Locally distributed synaptic potentiation in the hippocampus. Science 263:532-36

Severt WL, Biber TUL, Wu X-Q, Hecht NB, DeLorenzo RJ, Jakoi ER. 2000. The suppression of testis-brain RNA binding protein and kinesin heavy chain disrupts mRNA sorting in dendrites. J. Cell. Sci. 112:3691-702

Sheetz AJ, Nairn AC, Constantine-Paton M. 1997. N-methyl-D-aspartate receptor activation and visual activity induce elongation factor-2 phosphorylation in amphibian tecta: a role for N-methyl-D-aspartate receptors in controlling protein synthesis. Proc. Natl. Acad. Sci. USA 94:14770-75

Sheetz AJ, Nairn AC, Constantine-Paton M. 2000. NMDA receptor-mediated control of protein synthesis at developing synapses. Nat. Neurosci. 3:211-16

Smith WB, Aakalu GN, Tsung MI., Reis GF, Schuman EM. 1999. Neurotrophin-induced increase in local protein synthesis in cultured hippocampal neurons. Soc. Neurosci. Abstr. 25:467

Spacek J, Hartmann M. 1983. Threedimensional analysis of dendritic spines. I. Quantitative observations related to dendritic spines and synaptic morphology in cerebral and cerebellar cortices. Anat. Embryol. 167:289-310

Stanton PK, Sarvey JM. 1984. Blockade of long-term potentiation in rat hippocampal CA1 region by inhibitors of protein synthesis. J. Neurosci. 4:3080-84

Steward O. 1983. Polyribosomes at the base of dendritic spines of CNS neurons: their possible role in synapse construction and modification. Cold Spring Harbor Symp. Quant. Biol. 48:745-59 
Steward O. 1997. mRNA localization in neurons: a multipurpose mechanism. Neuron 18: 9-12

Steward O, Falk PM. 1986. Protein synthetic machinery at postsynaptic sites during synaptogenesis; a quantitative study of the association between polyribosomes and developing synapses. J. Neurosci. 6: 412-23

Steward O, Falk PM, Torre ER. 1996. Ultrastructural basis for gene expression at the synapse: synapse-associated polyribosome complexes. J. Neurocytol. 25:717-34

Steward O, Fass B. 1983. Polyribosomes associated with dendritic spines in the denervated dentate gyrus: evidence for local regulation of protein synthesis during reinnervation. Prog. Brain Res. 58:131-36

Steward O, Halpain S. 1999. Lamina-specific synaptic activation causes domain-specific alterations in dendritic immunostaining for MAP2 and CAM kinase II. J. Neurosci. 15:7834-45

Steward O, Levy WB. 1982. Preferential localization of polyribosomes under the base of dendritic spines in granule cells of the dentate gyrus. J. Neurosci. 2:284-91

Steward O, Pollack A, Rao A. 1991. Evidence that protein constituents of postsynaptic membrane specializations are locally synthesized: time course of appearance of recently synthesized proteins in synaptic junctions. J. Neurosci. Res. 30:649-60

Steward O, Reeves TM. 1988. Protein synthetic machinery beneath postsynaptic sites on CNS neurons: association between polyribosomes and other organelles at the synaptic site. J. Neurosci. 8:176-84

Steward O, Ribak CE. 1986. Polyribosomes associated with synaptic sites on axon initial segments: localization of protein synthetic machinery at inhibitory synapses. $\mathrm{J}$. Neurosci. 6:3079-85

Steward O, Singer RH. 1997. The intracellular mRNA sorting system: postal zones, zip codes, mail bags and mail boxes. In $m R N A$ Metabolism and Post-Transcriptional Gene
Regulation, ed. JB Hartford, DR Morris, pp. 127-46. New York: Wiley-Liss

Steward O, Wallace CS, Lyford GL, Worley PF. 1998. Synaptic activation causes the mRNA for the IEG Arc to localize selectively near activated postsynaptic sites on dendrites. Neuron 21:741-51

Tang SJ, Meulemans D, Vasquez L, Schuman EM. 1999. The role of a rat staufen-like protein in dendritic RNA targeting of hippocampal neurons. Proc. Annu. Meet. Soc. Neurosci. 25:468

Tang SJ, Smith WB, Schuman ME. 1998. Identification of components of a translational signaling pathway at synaptic sites in the hippocampus. Proc. Annu. Meet. Soc. Neurosci. $24: 328$

Tongiorgi E, Righi M, Cattaneo A. 1997. Activity-dependent dendritic targeting of BDNF and TrkB mRNAs in hippocampal neurons. J. Neurosci. 17:9492-505

Torre ER, Steward O. 1996. Protein synthesis within dendrites: distribution of the endoplasmic reticulum and the Golgi apparatus in dendrites of hippocampal neurons in culture. J. Neurosci. 16:5967-78

Valentine G, Chakravarty S, Sarvey J, Bramham C, Herkenham M. 2000. Fragile X (fmr1) mRNA expression is differentially regulated in two adult models of activity-dependent gene expression. Mol. Brain Res. 75:337-41

Watson JB, Coulter PM, Margulies JE, de Lecea L, Danielson PE, et al. 1994. G-protein gamma7 subunit is selectively expressed in medium-sized neurons and dendrites of the rat neostriatum. J. Neurosci. Res. 39:108-16

Weiler IJ, Greenough WT. 1991. Potassium ion stimulation triggers protein translation in synaptoneuronsomal polyribosomes. Mol. Cell. Neurosci. 2:305-14

Weiler IJ, Greenough WT. 1993. Metabotropic glutamate receptors trigger postsynaptic protein synthesis. Proc. Natl. Acad. Sci. USA 90:7168-71

Weiler IJ, Irwin SA, Klintsova AY, Spencer CM, Brazelton AD, et al. 1997. Fragile X mental retardation protein is translated near 
synapses in response to neurotransmitter activation. Proc. Natl. Acad. Sci. USA 94:5395400

White G, Levy WB, Steward O. 1988. Evidence that associative interactions between afferents during the induction of long-term potentiation occur within local dendritic domains. Proc. Natl. Acad. Sci. USA 85: 2368-72

White G, Levy WB, Steward O. 1990. Spatial overlap between populations of synapses determines the extent of their associative interaction during the induction of long term potentiation and depression. J. Neurophysiol. 64:1186-98

Wickham L, Duchaine T, Luo M, Nabi IR, DesGroseillers L. 1999. Mammalian staufen is a double-stranded RNA- and tubulin-binding protein which localizes to the rough endoplasmic reticulum. Mol. Cell. Biol. 19:222030

Wu L, Wells D, Tay J, Mendis D, Abborr M-A, et al. 1998. CPEB-mediated cytoplasmic polyadenylation and the regulation of experience-dependent translation of alphaCaMKII at synapses. Neuron 21:1129-39 


\section{CONTENTS}

PDZ DOMAINS AND THE ORGANIZATION OF

SUPRAMOLECULAR COMPLEXES, Morgan Sheng, Carlo Sala

THE ROLE AND REGULATION OF ADENOSINE IN THE CENTRAL

TOUCH AND GO: Decision-Making Mechanisms in Somatosensation,

SYNAPTIC MODIFICATION BY CORRELATED ACTIVITY: Hebb"s

Postulate Revisited, Guo-qiang Bi, Mu-ming Poo

AN INTEGRATIVE THEORY OF PREFRONTAL CORTEX

FUNCTION, Earl K. Miller, Jonathan D. Cohen

THE PHYSIOLOGY OF STEREOPSIS, B. G. Cumming, G. C.

DeAngelis

PARANEOPLASTIC NEUROLOGIC DISEASE ANTIGENS: RNA-

Binding Proteins and Signaling Proteins in Neuronal Degeneration, Kiran

Musunuru, Robert B. Darnell

ODOR ENCODING AS AN ACTIVE, DYNAMICAL PROCESS:

Experiments, Computation, and Theory, Gilles Laurent, Mark Stopfer,

Rainer W Friedrich, Misha I Rabinovich, Alexander Volkovskii, Henry

DI Abarbanel

PROTEIN SYNTHESIS AT SYNAPTIC SITES ON DENDRITES,

Oswald Steward, Erin M. Schuman

SIGNALING AND TRANSCRIPTIONAL MECHANISMS IN

PITUITARY DEVELOPMENT, Jeremy S. Dasen, Michael G. Rosenfeld NEUROPEPTIDES AND THE INTEGRATION OF MOTOR

RESPONSES TO DEHYDRATION , Alan G. Watts

THE DEVELOPMENTAL BIOLOGY OF BRAIN TUMORS, Robert

Wechsler-Reya, Matthew P. Scott

385

TO EAT OR TO SLEEP? OREXIN IN THE REGULATION OF

FEEDING AND WAKEFULNESS, Jon T. Willie, Richard M. Chemelli,

429

Christopher M. Sinton, Masashi Yanagisawa

SPATIAL PROCESSING IN THE BRAIN: The Activity of Hippocampal

Place Cells, Phillip J. Best, Aaron M. White, Ali Minai

459

THE VANILLOID RECEPTOR: A Molecular Gateway to the Pain

Pathway, Michael J Caterina, David Julius

487

PRION DISEASES OF HUMANS AND ANIMALS: Their Causes and

Molecular Basis, John Collinge

519

VIKTOR HAMBURGER AND RITA LEVI-MONTALCINI: The Path to

the Discovery of Nerve Growth Factor, W. Maxwell Cowan

551

EARLY DAYS OF THE NERVE GROWTH FACTOR PROTEINS,

Eric M. Shooter

601

SEQUENTIAL ORGANIZATION OF MULTIPLE MOVEMENTS:

Involvement of Cortical Motor Areas, Jun Tanji

631

INFLUENCE OF DENDRITIC CONDUCTANCES ON THE INPUT-

OUTPUT PROPERTIES OF NEURONS, Alex Reyes 
NEUROTROPHINS: Roles in Neuronal Development and Function, Eric

$J$ Huang, Louis F Reichardt

677

CONTRIBUTIONS OF THE MEDULLARY RAPHE AND

VENTROMEDIAL RETICULAR REGION TO PAIN MODULATION

737

AND OTHER HOMEOSTATIC FUNCTIONS, Peggy Mason

ACTIVATION, DEACTIVATION, AND ADAPTATION IN

VERTEBRATE PHOTORECEPTOR CELLS, Marie E Burns, Denis A

Baylor

779

ACTIVITY-DEPENDENT SPINAL CORD PLASTICITY IN HEALTH

AND DISEASE, Jonathan $R$ Wolpaw, Ann $M$ Tennissen

807

QUANTITATIVE GENETICS AND MOUSE BEHAVIOR, Jeanne $M$

Wehner, Richard A Radcliffe, Barbara J Bowers

845

EARLY ANTERIOR/POSTERIOR PATTERNING OF THE

MIDBRAIN AND CEREBELLUM, Aimin Liu, Alexandra L Joyner

869

NEUROBIOLOGY OF PAVLOVIAN FEAR CONDITIONING, Stephen

Maren

897

$\{\{$ alpha $\}$-LATROTOXIN AND ITS RECEPTORS: Neurexins and

CIRL/Latrophilins, Thomas C Südhof

IMAGING AND CODING IN THE OLFACTORY SYSTEM, John $S$

Kauer, Joel White

THE ROLE OF THE CEREBELLUM IN VOLUNTARY EYE

MOVEMENTS, Farrel R Robinson, Albert F Fuchs

ROLE OF THE REELIN SIGNALING PATHWAY IN CENTRAL

NERVOUS SYSTEM DEVELOPMENT, Dennis S Rice, Tom Curran

HUMAN BRAIN MALFORMATIONS AND THEIR LESSONS FOR

NEURONAL MIGRATION, M Elizabeth Ross, Christopher A Walsh

MORPHOLOGICAL CHANGES IN DENDRITIC SPINES

ASSOCIATED WITH LONG-TERM SYNAPTIC PLASTICITY, Rafael

Yuste, Tobias Bonhoeffer

STOPPING TIME: The Genetics of Fly and Mouse Circadian Clocks,

1091

Ravi Allada, Patrick Emery, Joseph S. Takahashi, Michael Rosbash

NEURODEGENERATIVE TAUOPATHIES, Virginia M-Y Lee, Michel

Goedert, John Q Trojanowski

MATERNAL CARE, GENE EXPRESSION, AND THE

TRANSMISSION OF INDIVIDUAL DIFFERENCES IN STRESS

933

963

981

1005

1041

REACTIVITY ACROSS GENERATIONS, Michael J Meaney

NATURAL IMAGE STATISTICS AND NEURAL

REPRESENTATION, Eero P Simoncelli, Bruno A Olshausen

1071

Nerve Growth Factor Signaling, Neuroprotection, and Neural Repair,

Michael V Sofroniew, Charles L Howe, William C Mobley

112

FLIES, GENES, AND LEARNING, Scott Waddell, William G Quinn

1161

1193

1217

1283 